\title{
ORIGINALARTICLE
}

\section{Scrotal circumference, bodyweight and serum testosterone concentration of Red Sokoto weaner bucks as influenced by dry season crop-residue supplementation}

Bunmi Sherifat MALAU-ADULI, ${ }^{1}$ Lawrence EDUVIE, ${ }^{2}$ Clarence LAKPINI $^{2}$ and Aduli Enoch Othniel MALAU-ADULI ${ }^{2}$

${ }^{1}$ Department of Animal Science and ${ }^{2}$ National Animal Production Research Institute, Ahmadu Bello University, Zaria, Nigeria

\begin{abstract}
The effect of dry season supplementation with crop-residue-based rations on bodyweight, scrotal circumference and serum testosterone concentrations in Red Sokoto weaner bucks at 5, 6 and 7 months of age was investigated in the present study. There were 7 treatment groups which were fed a positive control ration (conventional concentrate) fed at 1 and $2 \%$ of the bucks' bodyweights (Rations $1 \mathrm{~A}$ and $2 \mathrm{~A}$ ), two crop-residue-based test rations each fed at 1 and $2 \%$ of bodyweight (1B, $2 \mathrm{~B}, 1 \mathrm{C}$ and $2 \mathrm{C}$ ), and a negative control that was unsupplemented (Ration D). All treatment groups had ad libitum access to natural pastures and Digitaria smutsii hay as a basal diet. Bodyweight and scrotal circumference of the bucks significantly increased $(P<0.05)$ with age from $5.9 \mathrm{~kg}$ to $10.2 \mathrm{~kg}$, and $4.40 \mathrm{~cm}$ to $6.95 \mathrm{~cm}$, at 5 and 7 months of age, respectively. Bucks on Ration D (unsupplemented group) had the lowest bodyweight and scrotal circumference. Bucks on Ration 2A showed a significant increase in basal testosterone concentration from $0.32 \mathrm{ng} / \mathrm{mL}$ at 5 months of age to $0.65 \mathrm{ng} / \mathrm{mL}$ at 7 months of age. Peak testosterone concentration also increased from $1.0 \mathrm{ng} / \mathrm{mL}$ at 5 months to $2.8 \mathrm{ng} / \mathrm{mL}$ at $7 \mathrm{months}$ of age. Bucks on test Ration $2 \mathrm{C}$ had higher bodyweights $(6.75,8.00$ and $10.00 \mathrm{~kg}$ at 5,6 and 7 months of age, respectively) than bucks on the other test Ration B $(6.20,7.20$ and $8.50 \mathrm{~kg}$, respectively). There were no significant differences between the two test rations with regard to scrotal circumferences of the bucks at all ages. However, at 7 months of age, bucks on test Ration $2 \mathrm{C}$ had significantly higher peak testosterone concentration $(1.80 \mathrm{ng} / \mathrm{mL})$ than their counterparts on test Ration 2B (1.30 ng/mL). The secretory patterns of testosterone were episodic and pulsatile in nature. It was concluded that crop-residue supplementation in prepubertal Red Sokoto bucks has a significant influence on their bodyweight, scrotal circumference and testosterone production. Test Ration C was a cheap, affordable and better crop-residue-based ration for optimal reproductive performance than test Ration $\mathrm{B}$.
\end{abstract}

KEYWORDS: bodyweight, crop-residue, Red Sokoto bucks, scrotal circumference, testosterone.

\section{INTRODUCTION}

The Red Sokoto goat is found throughout the subhumid and semiarid zones of Nigeria. It is a mediumsized breed with reddish-brown coat color with a mature average liveweight of $30 \mathrm{~kg}$ and is kept for its milk, meat and skin. Detailed descriptions of its herd size (Gefu \& Adu 1982), production (Mathewman 1980; Otchere et al. 1987), lactation (Ehoche \& Buvanendran 1983) and reproductive performance (Adu et al. 1979) have been documented. The dry season is a critical period for small ruminant farmers in the subhumid zone of Nigeria because of feed scarcity.

Correspondence: Aduli Enoch Othniel Malau-Aduli, Laboratory of Animal Breeding and Reproduction, National Agricultural Research Center for Western Region, 60 Yoshinaga, Kawai, Oda-shi, Shimane-ken 694-0013, Japan. (Email: aduli40@yahoo.co.uk, aduli@affrc.go.jp)

Received 21 August 2002; accepted for publication 16 December 2002. 
Smallholder goat farmers resort to crop residues from postharvest farm operations to feed their animals. However, these crop residues are limiting in nutrients necessary for maintenance and production. Therefore, supplementary feeding to boost the nutritional status of the animals has been recommended (Alawa $\delta$ Umunna 1993). However, feed supplementation packages for improving reproductive performance of small ruminants during the long dry periods of the year are currently not available in Nigeria.

The purpose of proper management of a young male animal is to improve growth rate and to enable it to produce optimum levels of good quality semen at the earliest possible age. However, the onset of puberty is more closely related to bodyweight than to age (Setchell et al. 1965). The effect of improving protein intake on age at onset of puberty in Zebu bulls under range conditions has been reported (Oyedipe et al. 1981; Rekwot et al. 1987). The concentrations of serum testosterone have been shown to increase linearly with advancing age in bulls (Lunstra et al. 1978). Furthermore, Bos indicus bulls have been reported to have lower fertility than Bos taurus bulls (Fields et al. 1982 ) and this is attributed to smaller testis size (Oyedipe et al. 1981). Strategic intervention with supplementary feeding in the dry season of the year is likely to have a great impact on the nutritional deficiencies observed in tropical animals during this period. Vital information on testosterone profiles for monitoring reproductive performance in Red Sokoto bucks is lacking. Therefore, this present study was designed to investigate the influence of dry season crop-residue supplementation on bodyweight, scrotal circumference and testosterone concentrations of Red Sokoto weaner bucks in order to recommend to smallholder goat farmers a cheap, affordable and better cropresidue-based ration for optimal reproductive performance.

\section{MATERIALS AND METHODS}

\section{Location and climatic conditions}

The experiment was conducted in the Goat Experimental Unit of the Small Ruminant Research Programme at the National Animal Production Research Institute, Shika, Zaria, Nigeria. Shika falls between latitudes 11 and $12^{\circ} \mathrm{N}$ and between longitudes 7 and $8^{\circ} \mathrm{E}$, with an altitude of $640 \mathrm{~m}$ above sea level. Shika is located within the Northern Guinea Savannah Zone and average annual rainfall and temperature are
$1107 \mathrm{~mm}$ and $24.4^{\circ} \mathrm{C}$, respectively. The seasonal distribution of the annual rainfall is approximately $0.1 \%$ $(11.0 \mathrm{~mm})$ in the late dry season (January-March), $25.8 \%(285.6 \mathrm{~mm})$ in the early wet season (AprilJune), $69.6 \%(770.4 \mathrm{~mm})$ in the late wet season (July-September) and $4.5 \%(40.0 \mathrm{~mm})$ in the early dry season (October-December). The experiments were conducted during the dry seasons (from October to March). The animals were routinely dewormed with anthelmintic drugs and dipped in an acaricide (Asuntol, Bayer Nigeria, Essex, UK) solution against ectoparasites. The animals were housed in well-ventilated pens during the night after grazing during the day.

\section{Experimental animals}

Twenty-eight Red Sokoto weaner bucks approximately 4 months of age were balanced for weight and blocked into 7 treatment groups of 4 animals per group (Table 1). They were group-fed for 2 hours each day between 08.00 and 10.00 hours with the appropriate ration. Thereafter, they were released into a specified paddock to graze natural pastures and Digitaria smutsii hay ad libitum, under the supervision of a herdsman, until 18.00 hours. An initial adjustment period of 3 weeks was allowed so that the animals could get used to their respective feeds and pens before measurements. The present study lasted for 3 months. Just before the commencement of the study (i.e. at 4 months of age), measurements of bodyweight and scrotal circumference for all the treatment groups were taken. Subsequently, these parameters were measured at 5, 6 and 7 months of age in the experimental animals. The component ingredients and chemical composition of the experimental rations are shown in Tables 2 and 3, respectively.

\section{Hormonal assay}

Blood samples from the bucks in each treatment group were collected every $30 \mathrm{~min}$ for $6 \mathrm{~h}$ (from 06.00 to 12.00 hours) at 5, 6 and 7 months of age by jugular venipuncture. Serum samples were harvested and stored at $-20^{\circ} \mathrm{C}$ until analyzed. Thus, a total of 273 blood samples were collected and the serum was analyzed for testosterone concentration. Serum testosterone concentrations were determined using a non-extraction, 'Coat-A-Count' solid phase testosterone radio-immunoassay kit (Diagnostic Products Corporation, Los Angeles, CA, USA). Human serum-based standards with testosterone concentrations of $0,0.3$, $1.0,3.0,10.0$ and $30.0 \mathrm{ng} / \mathrm{mL}$ were used. The assay 
Table 1 Component ingredients in the experimental rations

\begin{tabular}{|c|c|c|c|}
\hline Ration & Ingredients & $\begin{array}{l}\% \text { inclusion } \\
\text { (dry matter) }\end{array}$ & Remarks \\
\hline \multirow[t]{5}{*}{$1 \mathrm{~A}+$ Basal diet } & Maize & 40.00 & $\begin{array}{l}\text { Positive control (conventional concentrate) } \\
\text { offered at } 1 \% \text { of bodyweight }\end{array}$ \\
\hline & Wheat offal & 35.00 & \\
\hline & Cottonseed cake & 20.00 & \\
\hline & Bone meal & 3.00 & \\
\hline & Salt & 2.00 & \\
\hline \multirow[t]{5}{*}{$2 \mathrm{~A}+$ Basal diet } & Maize & 40.00 & $\begin{array}{l}\text { Positive control (conventional concentrate) } \\
\text { offered at } 2 \% \text { of bodyweight }\end{array}$ \\
\hline & Wheat offal & 35.00 & \\
\hline & Cottonseed cake & 20.00 & \\
\hline & Bone meal & 3.00 & \\
\hline & Salt & 2.00 & \\
\hline \multirow[t]{4}{*}{$1 \mathrm{~B}+$ Basal diet } & Guinea-corn bran & 39.50 & Test Ration 1 offered at $1 \%$ of bodyweight \\
\hline & Cowpea husk & 30.00 & \\
\hline & Groundnut haulms & 30.00 & \\
\hline & Salt & 0.50 & \\
\hline \multirow[t]{4}{*}{ 2B + Basal diet } & Guinea-corn bran & 39.50 & Test Ration 1 offered at $2 \%$ of bodyweight \\
\hline & Cowpea husk & 30.00 & \\
\hline & Groundnut haulms & 30.00 & \\
\hline & Salt & 0.50 & \\
\hline \multirow[t]{4}{*}{$1 \mathrm{C}+$ Basal diet } & Maize offal & 49.50 & Test Ration 2 offered at $1 \%$ of bodyweight \\
\hline & Groundnut shells & 20.00 & \\
\hline & Groundnut haulms & 30.00 & \\
\hline & Salt & 0.50 & \\
\hline \multirow[t]{4}{*}{$2 \mathrm{C}+$ Basal diet } & Maize offal & 49.50 & Test Ration 2 offered at $2 \%$ of bodyweight \\
\hline & Groundnut shells & 20.00 & \\
\hline & Groundnut haulms & 30.00 & \\
\hline & Salt & 0.50 & \\
\hline D (Basal Diet) & $\begin{array}{l}\text { Digitaria hay and natural } \\
\text { grazed pasture }\end{array}$ & Ad libitum & Negative control (unsupplemented) \\
\hline
\end{tabular}

procedure was as follows: to antibody coated tubes, $25 \mu \mathrm{L}$ of standard $(0,0.3,1.0,3.0,10.0$ and $30.0 \mathrm{ng} /$ $\mathrm{mL}$ ) or serum sample and $1 \mathrm{~mL}$ buffered $\left[{ }^{125} \mathrm{I}\right]$-labeled testosterone solution were added. The mixture was vortexed, incubated for $3 \mathrm{~h}$ at $37^{\circ} \mathrm{C}$ and decanted to remove all visible moisture and to separate bound from free testosterone. The tubes were placed in a gamma counter (Beckmann 4000, Beckmann Instruments Inc., Manchester, UK) and the potencies of the samples estimated using a linear logit log doseresponse curve. The antisera were highly specific for testosterone, the cross reactivities with androsteredione and dihydrotestosterone were 3.0 and $8.1 \%$, respectively, while the cross reactivity with other $\mathrm{C} 19$ steroids was $<3 \%$. The sensitivity of the assay was $0.081 \mathrm{ng} / \mathrm{mL}$, while intra and interassay coefficients of variation were 8.5 and $9.5 \%$, respectively. Mean basal testosterone levels were defined as the mean of the 6 lowest values observed during the 6 h sampling, while peak testosterone concentrations were defined as each single or series of values two-fold higher than mean basal concentration (Renaville et al. 1983).

\section{Digestibility trial}

Each buck was individually offered its appropriate corresponding ration to evaluate the digestibility of the diets. The animals used for the digestibility trial were 5 months old on average. The present study comprised a 2 week preliminary period of realimentation and adjustment, and one week of sample collection. The animals were housed in individual metabolism cages with facilities for separate collection of feces and urine. The animals were weighed at the beginning and end of the present study. Feces were collected each morning just before feeding. Ten percent of each daily fecal output was collected for chemical analyses. Samples of the different rations fed were taken daily and bulked, from which subsamples were taken for laboratory analysis. Also, samples of the individual feed ingredients were analyzed in the laboratory. Water was made available 
Table 2 Chemical composition of the major feed ingredients (dry matter basis, \%)

\begin{tabular}{llccrcr}
\hline Feedstuff & Dry matter & Crude protein & Crude fiber & Ash & Ether extract & Nitrogen-free extract \\
\hline Maize & 90.73 & 9.56 & 2.20 & 9.67 & 4.05 & 74.52 \\
Wheat offal & 87.60 & 16.90 & 11.30 & 6.40 & 3.80 & 61.60 \\
Cottonseed cake & 93.60 & 29.94 & 23.50 & 5.16 & 5.76 & 35.64 \\
Bone meal & 75.00 & 36.00 & 3.00 & 49.00 & 4.00 & 8.00 \\
Guinea corn bran & 93.33 & 7.60 & 24.80 & 6.95 & 3.01 & 59.90 \\
Cowpea husks & 91.41 & 7.10 & 33.40 & 7.14 & 0.65 & 58.91 \\
Groundnut haulms & 93.65 & 15.63 & 23.26 & 8.00 & 2.43 & 51.00 \\
Maize offal & 89.07 & 10.08 & 1.50 & 0.80 & 1.70 & 60.30 \\
Groundnut shells & 96.05 & 5.90 & 31.80 & 8.50 & 1.31 & 50.30 \\
\hline
\end{tabular}

Table 3 Chemical composition of the experimental diets (dry matter basis, \%)

\begin{tabular}{|c|c|c|c|c|c|c|c|}
\hline Ration & Dry matter & $\begin{array}{l}\text { Crude } \\
\text { protein }\end{array}$ & Ash & Ether extract & $\begin{array}{l}\text { Acid detergent } \\
\text { fiber }\end{array}$ & $\begin{array}{l}\text { Neutral } \\
\text { detergent fiber }\end{array}$ & Lignin \\
\hline Ration A & 93.87 & 17.19 & 13.85 & 14.08 & 20.00 & 40.01 & 4.64 \\
\hline Ration B & 94.97 & 9.54 & 10.55 & 10.43 & 38.10 & 68.42 & 8.94 \\
\hline Ration C & 95.94 & 10.38 & 11.97 & 12.45 & 36.65 & 54.74 & 8.23 \\
\hline Ration D, Hay & 94.78 & 4.75 & 8.47 & 2.40 & 49.14 & 74.73 & 9.49 \\
\hline Ration D, Natural pastures & 96.26 & 2.76 & 7.02 & 0.78 & 50.29 & 80.27 & 11.50 \\
\hline \multicolumn{8}{|c|}{ Calculated analysis of the experimental rations } \\
\hline & \multirow{2}{*}{\multicolumn{2}{|c|}{$\begin{array}{c}\text { Ration A } \\
17.05\end{array}$}} & \multicolumn{2}{|r|}{ Ration B } & \multicolumn{2}{|c|}{ Ration C } & \\
\hline $\mathrm{CP}(\%)$ & & & \multirow{2}{*}{\multicolumn{2}{|c|}{$\begin{array}{r}9.82 \\
10.29\end{array}$}} & \multirow{2}{*}{\multicolumn{2}{|c|}{$\begin{array}{l}10.85 \\
10.17\end{array}$}} & \\
\hline $\mathrm{ME}(\mathrm{MJ} / \mathrm{kg} \mathrm{DM})$ & \multicolumn{2}{|c|}{11.17} & & & & & \\
\hline
\end{tabular}

The metabolizable energy (ME) values of the experimental rations were calculated as per Alderman (1985) as follows:

$\mathrm{ME}(\mathrm{MJ} / \mathrm{kg} \mathrm{DM})=11.78+0.00654 \mathrm{CP}+(0.000665 \mathrm{EE})^{2}-\mathrm{CF}(0.00414 \mathrm{EE})-0.0118 \mathrm{~A}$, where CP, Crude Protein; EE, Ether Extract;

CF, Crude Fibre; A, Ash.

to the animals ad libitum. The inventory, abundance and palatability of the plant species in the grazed paddock was recorded as described by Lakpini et al. (1997).

\section{Proximate analyses}

Proximate analyses of feed and fecal samples were carried out by the AOAC (1980) methods. Dry matter of samples was determined in an oven at $105^{\circ} \mathrm{C}$ for $48 \mathrm{~h}$. Nitrogen determination was by the Micro Kjedahl method, while the Soxhlet extraction procedure was used for ether extraction. Crude fiber was determined by alternate refluxing with weak solutions of $\mathrm{H}_{2} \mathrm{SO}_{4}$ and $\mathrm{KOH}$. The detergent fiber fractions (neutral detergent fiber, acid detergent fiber and lignin) were determined according to Goering and Van Soest (1970).

\section{Statistical analysis}

Statistical analysis was carried out using the general linear model procedure of SAS (1987) in a $3 \times 2$ factorial ANOVA to test the effects of ration and feeding level on bodyweight, scrotal circumference and testosterone concentrations. Duncan's multiple range test was used in separating differences between significant means.

\section{RESULTS}

\section{Experimental rations}

The chemical composition of the individual feed ingredients and the experimental diets are shown in Tables 2 and 3, respectively. Table 3 shows that all the rations had high dry matter (DM) contents with a mean value of approximately $95 \%$. Ration A had the highest crude protein (CP) value of $17.19 \%$ followed by Rations $\mathrm{B}$ and $\mathrm{C}$ with 9.54 and $10.38 \%$, respectively. The CP value of the grazed pastures (dry season) was the lowest $(2.76 \%)$, while that of Digitaria hay was $4.75 \%$. The least ash content value was obtained in Ration D with the hay having $8.47 \%$ and the grazed pasture having $7.02 \%$. The highest ash content value of $13.85 \%$ was obtained in Ration A. Ration A also had the highest ether extract (EE) value of $14.08 \%$ and Ration D, the least $(0.78$ and $2.40 \%$ for grazed pasture and Digitaria hay, respectively). Acid 
Table 4 Mean nutrient intake, apparent digestibility coefficients and cost of the experimental diets

\begin{tabular}{|c|c|c|c|c|c|c|c|c|}
\hline Ration & $1 \mathrm{~A}$ & $2 \mathrm{~A}$ & $1 B$ & $2 \mathrm{~B}$ & $1 \mathrm{C}$ & $2 \mathrm{C}$ & $\mathrm{D}$ & SEM \\
\hline \multicolumn{9}{|l|}{ Nutrient intake (kg/day) } \\
\hline Dry matter intake & $0.24^{\mathrm{b}}$ & $0.47^{\mathrm{a}}$ & $0.21^{\mathrm{bc}}$ & $0.30^{\mathrm{ab}}$ & $0.23^{\mathrm{b}}$ & $0.42^{\mathrm{a}}$ & $0.15^{\mathrm{c}}$ & \pm 0.02 \\
\hline Crude protein intake & $0.044^{\mathrm{a}}$ & $0.087^{\mathrm{a}}$ & $0.012^{\mathrm{b}}$ & $0.017^{\mathrm{b}}$ & $0.032^{\mathrm{a}}$ & $0.072^{\mathrm{a}}$ & $0.009^{\mathrm{b}}$ & \pm 0.01 \\
\hline \multicolumn{9}{|l|}{ Apparent digestibility of nutrients (\%) } \\
\hline Dry matter & $84.3^{\mathrm{a}}$ & $83.0^{\mathrm{a}}$ & $62.5^{\mathrm{d}}$ & $60.5^{\mathrm{e}}$ & $75.8^{\mathrm{b}}$ & $67.8^{\mathrm{c}}$ & $56.4^{\mathrm{f}}$ & \pm 2.84 \\
\hline Crude protein & $90.6^{\mathrm{a}}$ & $89.2^{\mathrm{a}}$ & $69.5^{\mathrm{d}}$ & $65.5^{\mathrm{e}}$ & $82.7^{\mathrm{b}}$ & $78.1^{\mathrm{c}}$ & $48.4^{\mathrm{f}}$ & \pm 3.07 \\
\hline Neutral detergent fiber & $69.5^{\mathrm{a}}$ & $66.6^{\mathrm{b}}$ & $62.1 c^{d}$ & $61.9^{d}$ & $65.9^{\mathrm{b}}$ & $63.7^{c}$ & $60.1^{e}$ & \pm 3.23 \\
\hline Acid detergent fiber & $51.7^{\mathrm{a}}$ & $49.8^{\mathrm{a}}$ & $43.9^{\mathrm{bc}}$ & $42.8^{c}$ & $46.1^{\mathrm{b}}$ & $44.4^{\mathrm{bc}}$ & $42.3^{\mathrm{bc}}$ & \pm 5.01 \\
\hline $\begin{array}{l}\text { Economic analysis of the feeds } \\
\text { Cost of feed consumed per animal } \\
\text { per day (Naira)* }\end{array}$ & $2.19^{\mathrm{b}}$ & $4.42^{\mathrm{a}}$ & $0.50^{\mathrm{e}}$ & $1.06^{\mathrm{d}}$ & $0.83 \mathrm{~d}^{\mathrm{e}}$ & $1.55^{\mathrm{c}}$ & - & \pm 0.15 \\
\hline
\end{tabular}

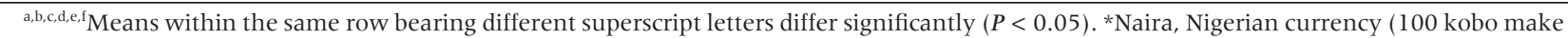
1 Naira and current exchange rate is US\$1 = 140 Naira).

detergent fiber (ADF), neutral detergent fiber (NDF) and lignin contents were least in Ration A with values of $20.00 \%, 40.01 \%$ and $4.64 \%$, respectively. Ration D however, contained the highest ADF, NDF and lignin values of $49.14 \%, 74.73 \%$ and $9.49 \%$ for hay and $50.29,80.27$ and $11.5 \%$ for grazed pasture, respectively. The calculated chemical analysis of the experimental rations (Table 3) reveals that Ration A had a CP content of $17.05 \%$ while the test Rations B and C had 9.82 and $10.85 \%$, respectively. Ration A also had a metabolizable energy (ME) of $11.17 \mathrm{MJ} / \mathrm{kg} \mathrm{DM}$, while Rations B and C had 10.29 and $10.17 \mathrm{MJ} / \mathrm{kg} \mathrm{DM}$, respectively. Table 4 shows the DM and CP intakes and digestibilities of the nutrients. The table shows that generally, the supplemented groups had significantly higher $(P<0.05)$ DM and CP intakes and digestibilities than the unsupplemented group except animals on Ration B that had similar values to the unsupplemented group. It was also evident that increasing the level of supplementation also resulted in increased DM and $\mathrm{CP}$ intakes of all the experimental rations, with these increases being significant $(P<0.05)$ and similar for Rations A and C. It was also observed that supplementation increased the digestibility of all the nutrients. However, animals on Ration B recorded very poor digestibility values and their counterparts in the unsupplemented group had the lowest. Even though the digestibility of nutrients decreased with increasing levels of supplementation, these decreases were not significant $(P>0.05)$. Ration lA (the conventional concentrate at $1 \%$ of bodyweight) gave the highest digestibility values. A comparison of the unsupplemented animals with all the other treatment groups reveals that DM digestibility improved by a range of 4.1-27.9 points and CP digestibility by $17.1-42.2$ points, the highest being in animals on Ration A at $1 \%$ level. Similar improvement trends were also noticeable for neutral detergent fiber (NDF) and acid detergent fiber (ADF). A simple economic analysis (Table 4) revealed that the conventional concentrate feed was the most expensive for supplementation particularly, at the $2 \%$ level ( 4.42 naira per animal per day). Of the two tested crop-residue rations, Ration IB was significantly cheaper $(P<0.05)$ than Rations $2 \mathrm{~B}$ and $2 \mathrm{C}$, but similar to Ration $1 \mathrm{C}$.

\section{Bodyweight, scrotal circumference and testosterone concentration}

The means \pm SE of prestudy measurements of bodyweight and scrotal circumference of the experimental animals were $5.8 \pm 0.3 \mathrm{~kg}$ and $4.0 \pm 0.2 \mathrm{~cm}$, respectively. The results of the present study showed that there were significant $(P<0.05)$ bodyweight differences among bucks fed different rations and at the different ages (Table 5). At 5 months of age, bucks on Rations 2A and 2C were significantly heavier (6.80 and $6.75 \mathrm{~kg}$, respectively) than bucks on all other rations, except for Ration $1 \mathrm{~A}(6.50 \mathrm{~kg})$. Bucks on Ration D had the lowest weight $(5.90 \mathrm{~kg})$ but it was not significantly different from Rations 1A, 1B, 1C and 2B. At 6 and 7 months of age, the trends were similar, with bucks on Rations $2 \mathrm{~A}$ and $2 \mathrm{C}$ weighing more than the others and those on Ration D ranking the lowest in weight (Table 5). Within treatments, there were significant age effects in that all the bucks increased in weight as their ages increased from 5 to 7 months. At 5 and 6 months of age, there were no significant differences between bucks on different rations in terms of scrotal circumference, but at 7 months of age, bucks 
Table 5 Effect of ration supplementation on bodyweight and scrotal circumference at 5,6 and 7 months of age

\begin{tabular}{|c|c|c|c|c|c|c|c|}
\hline Ration & $1 \mathrm{~A}$ & $2 \mathrm{~A}$ & $1 \mathrm{~B}$ & $2 \mathrm{~B}$ & $1 \mathrm{C}$ & $2 \mathrm{C}$ & $\mathrm{D}$ \\
\hline \multicolumn{8}{|c|}{ Bodyweight (kg) at: } \\
\hline 5 months & $6.50^{\mathrm{ab}}$ & $6.80^{\mathrm{a}}$ & $6.00^{\mathrm{b}}$ & $6.20^{\mathrm{b}}$ & $6.20^{\mathrm{b}}$ & $6.75^{\mathrm{a}}$ & $5.90^{\mathrm{b}}$ \\
\hline 6 months & $7.80^{\mathrm{a}}$ & $8.00^{\mathrm{a}}$ & $6.70^{c}$ & $7.20^{\mathrm{bc}}$ & $7.75^{\mathrm{ab}}$ & $8.00^{\mathrm{a}}$ & $6.20^{\mathrm{d}}$ \\
\hline 7 months & $9.50^{\mathrm{b}}$ & $10.20^{\mathrm{a}}$ & $8.20^{c}$ & $8.50^{c}$ & $9.50^{\mathrm{b}}$ & $10.00^{\mathrm{ab}}$ & $7.50^{\mathrm{d}}$ \\
\hline \multicolumn{8}{|c|}{ Scrotal circumference $(\mathrm{cm})$ at: } \\
\hline 5 months & 4.60 & 4.40 & 4.40 & 4.70 & 4.60 & 4.50 & 4.40 \\
\hline 6 months & 4.90 & 4.70 & 4.65 & 4.90 & 4.85 & 4.85 & 4.75 \\
\hline 7 months & $6.20^{\mathrm{b}}$ & $6.95^{\mathrm{a}}$ & $6.35^{\mathrm{b}}$ & $6.20^{\mathrm{b}}$ & $6.30^{\mathrm{b}}$ & $6.30^{\mathrm{b}}$ & $6.25^{\mathrm{b}}$ \\
\hline
\end{tabular}

Table 6 Effect of ration supplementation on basal and peak testosterone concentrations at 5,6 and 7 months of age

\begin{tabular}{|c|c|c|c|c|c|c|c|}
\hline Ration & $1 \mathrm{~A}$ & $2 \mathrm{~A}$ & 1B & $2 \mathrm{~B}$ & $1 \mathrm{C}$ & $2 \mathrm{C}$ & $\mathrm{D}$ \\
\hline \multicolumn{8}{|c|}{ Basal testosterone concentration $(\mathrm{ng} / \mathrm{mL})$ at: } \\
\hline 5 months & 0.30 & 0.32 & 0.30 & 0.33 & 0.30 & 0.32 & 0.31 \\
\hline 6 months & 0.30 & 0.33 & 0.31 & 0.34 & 0.31 & 0.32 & 0.33 \\
\hline 7 months & $0.32^{\mathrm{b}}$ & $0.65^{\mathrm{a}}$ & $0.31^{b}$ & $0.34^{\mathrm{b}}$ & $0.33^{\mathrm{b}}$ & $0.34^{\mathrm{b}}$ & $0.34^{\mathrm{b}}$ \\
\hline \multicolumn{8}{|c|}{ Peak testosterone concentration $(\mathrm{ng} / \mathrm{mL})$ at: } \\
\hline 5 months & 1.00 & 1.00 & 1.10 & 1.00 & 1.20 & 1.20 & 1.10 \\
\hline 6 months & 1.00 & 1.10 & 1.20 & 1.20 & 1.20 & 1.30 & 1.10 \\
\hline 7 months & $1.30^{\mathrm{b}}$ & $2.80^{\mathrm{a}}$ & $1.30^{\mathrm{b}}$ & $1.30^{\mathrm{b}}$ & $1.50^{\mathrm{b}}$ & $1.80^{\mathrm{b}}$ & $1.30^{\mathrm{b}}$ \\
\hline
\end{tabular}

${ }^{\mathrm{a}, \mathrm{b}}$ Means within rows bearing different superscripts are significantly different $(P<0.05)$.

on Ration 2A had significantly larger scrotal circumferences $(6.95 \mathrm{~cm})$ than all the other groups.

Table 6 shows the episodic peaks in testosterone concentration of the experimental animals. The trend was similar for both the basal and peak testosterone concentrations. In this regard, there were no significant differences between all the treatment groups at 5 and 6 months of age, but at 7 months, bucks on Ration $2 \mathrm{~A}$ recorded significantly higher values than all the others. The fluctuations in testosterone concentrations in bucks at 7 months of age during a $6 \mathrm{~h}$ period at 30 minute intervals are presented in Fig. 1. Bucks on Ration 2A had significantly $(P<0.05)$ higher peak testosterone concentrations $(2.8 \mathrm{ng} / \mathrm{mL})$ than the other bucks $(1.3-1.8 \mathrm{ng} / \mathrm{mL})$.

\section{DISCUSSION}

The quantity and type of ingredients used in formulating the rations influenced their chemical compositions. In Ration A, the inclusion of wheat offal and cottonseed cake boosted the protein level of the ration, giving it a value of $17.19 \%$. This value is higher than the recommended CP level of $15 \%$ for optimum maintenance of production by Nuru (1985) and 8.9-16.0\% by NRC (1975). The metabolizable energy (ME) value of Ration A (11.17 MJ/kg DM) is also higher than the $9.5 \mathrm{MJ} / \mathrm{kg} \mathrm{DM}$ recommended for maintenance by INRA (1988). Rations B and C had similar CP and ME values indicating that they are isocaloric and isonitrogenous rations. The preponderance of crop residues in Rations B and C was responsible for their high crude fiber and lignin levels. The current study showed that in spite of Rations B and C being isocaloric and isonitrogenous, animals on Ration $\mathrm{C}$ had better intakes and digestibilities than those on Ration B, possibly because of the low palatability, hence low voluntary intake, and poor digestibility of Ration B.

The observed higher digestibilities of DM, CP, NDF and $\mathrm{ADF}$ at the $1 \%$ level in comparison to the $2 \%$ level can be attributed to the higher feed intake at the $2 \%$ level of inclusion. It has been established that higher feed intake results in a faster rate of passage of digesta from the reticulo-rumen (Swan $\delta$ Lamming 1967). This does not allow for effective degradation, hence lowering the digestibility of feed. Increasing the level of crop residue inclusion in the diet also increases the amount of lignin, which depresses the digestibility of the ration (McDonald et al. 1988), because the rate of microbial colonization of a feed with high fiber 
(a)

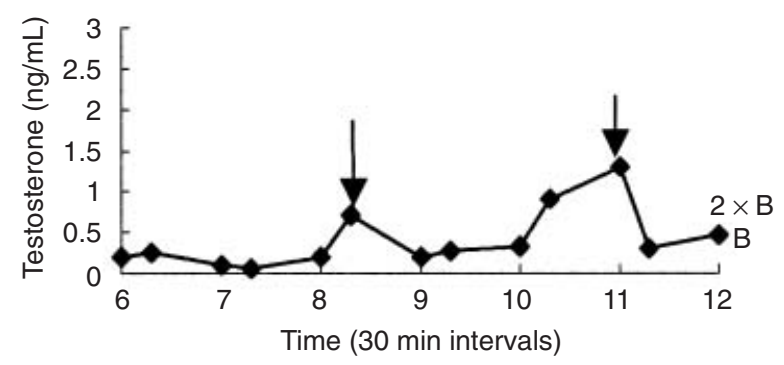

(b)

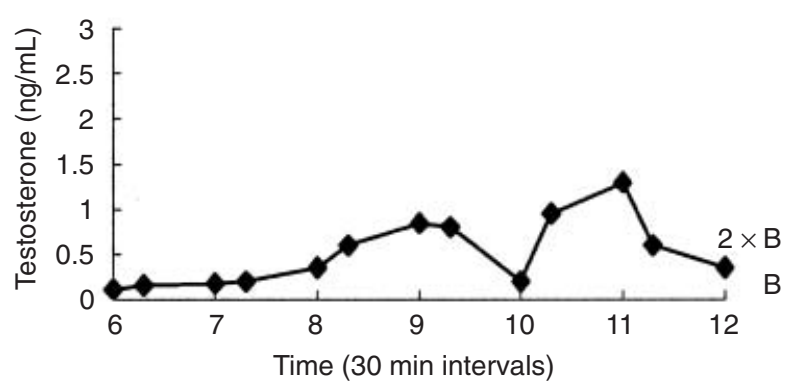

(c)

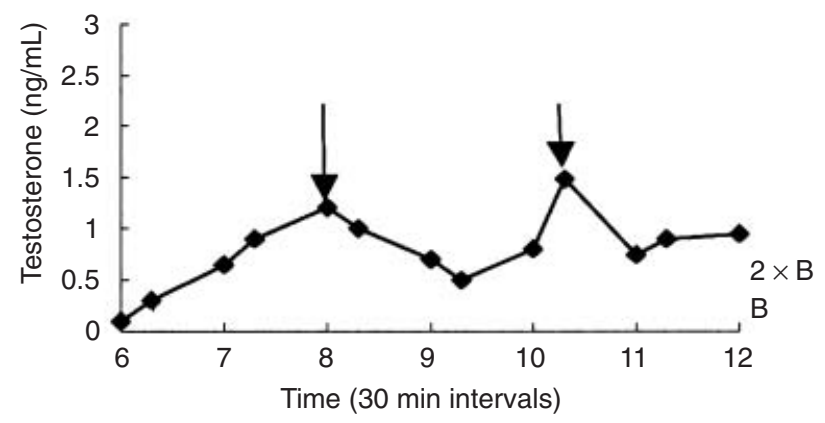

(d)

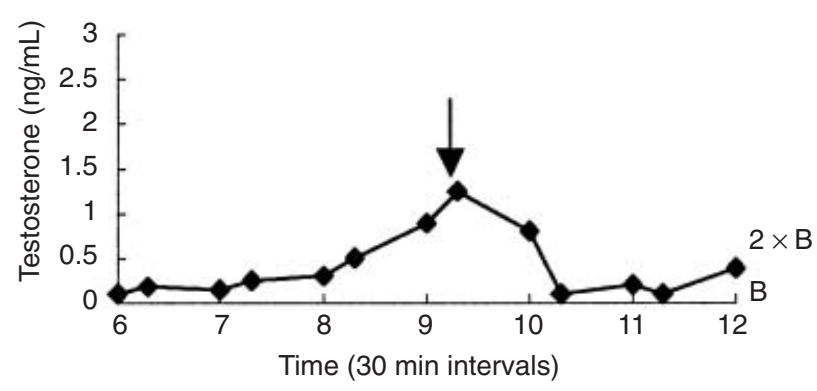

Fig. 1 Testosterone profiles of Red Sokoto weaner bucks at 7 months of age showing basal (B) and episodic peaks (arrows) in different treatment groups, fed at $1 \%$ of bodyweight. Fig. $1 \mathrm{~d}$ is the unsupplemented group. (a)

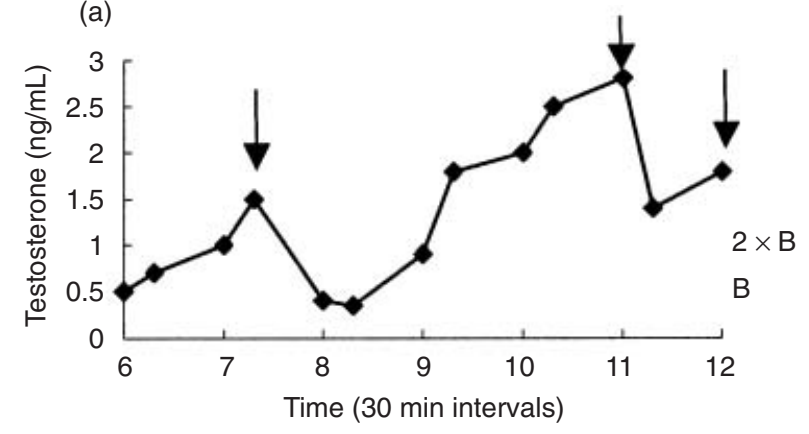

(b)

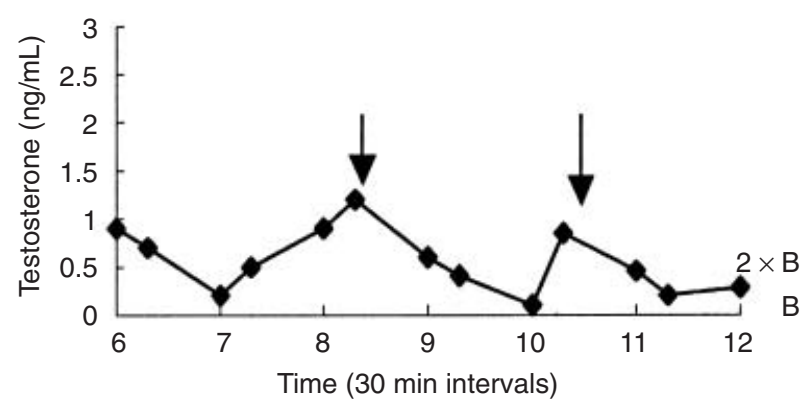

(c)

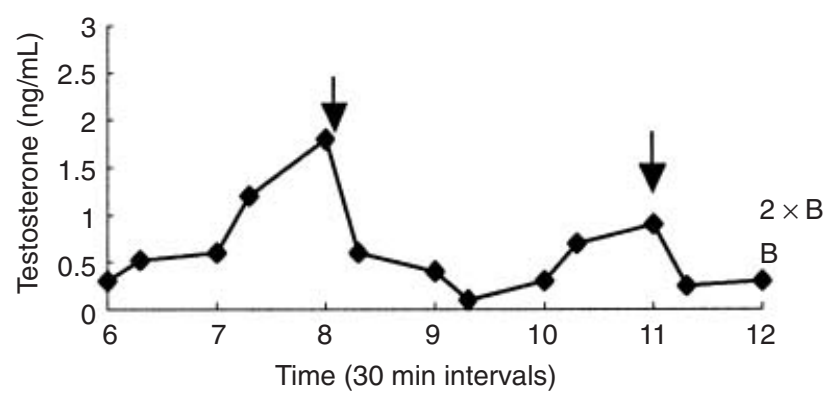

Fig. 2 Testosterone profiles of Red Sokoto weaner bucks at 7 months of age showing basal (B) and episodic peaks (arrows) in different treatment groups, fed at $2 \%$ of bodyweight.

content is comparatively lower (Silva \& Orskov 1988). The poor intake and digestibility values obtained for the unsupplemented animals is a result of the fact that Ration D had crude protein levels that are below the recommended minimum values for maintenance. This shows that there is a need for dry season supplementation in goats because the available feeds at that time are limiting in crude protein.

Of the two tested rations, Ration $\mathrm{C}$ seemed to have produced better intakes and digestibilities in the animals, possibly because of the composition of the rations. It contained maize offal which has very low 
fiber content (Alawa \& Umunna 1993), groundnut haulms which have been demonstrated to be better quality roughage than Digitaria smutsii hay and contain adequate protein to maintain ruminants without any form of supplementation during periods of feed scarcity (Ikhatua \& Adu 1984). The groundnut shells fed to the animals were also crushed before inclusion into the ration as suggested by Alawa and Umunna (1993). This must have helped to improve their consumption and digestibility. Even though Ration B contained groundnut haulms, the combination of Guinea corn bran and cowpea husk which had low crude protein percentages, must have reduced the intake and digestibility of the ration. Alhassan et al. (1984) observed lower digestibility values in sheep and goats (48.8 and $56.3 \%$, respectively) compared with cattle $(73.6 \%)$ when they were fed cowpea vines. This might imply that cattle do better on cowpea residues than do small ruminants. From the economic analysis, the high cost of the conventional concentrate ration shows that it is beyond the reach of a typical smallholder goat farmer, whereas the crop-residue-based rations seem quite affordable. Even though Ration B had the lowest cost, it was obvious that it had lower intake and digestibility compared to Ration C, meaning, in essence, that Ration $\mathrm{C}$ had a better efficiency of utilization.

The results from the present study have shown the significance of supplementation on bodyweight gain, scrotal circumference and testosterone concentration. Dyrmundsson (1973) reported that supplementation enhanced the ability of lambs to reach puberty and the results from the present study substantiate his observations. Bodyweight, scrotal circumference and testosterone concentrations have all been observed to increase with age in bulls (Karg et al. 1976; Lunstra et al. 1978; Rekwot et al. 1987). The observation in the present study that testosterone concentrations increased gradually as the bucks approached puberty supports the hypothalamic desensitization theory of sexual maturation (Odell \& Swedloff 1974; Lacroix \& Pelletier 1979). Nutritional imbalances may primarily affect the anterior pituitary or hypothalamus, thus interfering with normal luteinizing hormone and follicle-stimulating hormone production (Gerioff 1986).

The peak and basal testosterone concentrations reported in this present study are lower in value than those reported by Rekwot et al. (1997) in Bunaji bulls. This may be a result of species differences and also the duration of the present study ( 3 months) being less than the present study (7 months). However, the testosterone concentrations of the bucks showed fluctu- ations, with one to three distinct episodic peaks, in agreement with the findings of Sanwal et al. (1974), Agarwal et al. (1983) and Rekwot et al. (1987) in bulls. The exact significance of these episodic peaks is not clear but may be related to the sexual and behavioral states of the animals or adjustments to photoperiodicity, temperature and postural states of the animals (Sanwal et al. 1974). The testosterone profiles observed were episodic, pulsatile or temporal in nature and this agrees with the results obtained in bulls (Agarwal et al. 1983; Rekwot et al. 1987).

In conclusion, the present study demonstrates that supplementation aids bodyweight gain and peak testosterone concentration, with bucks on Ration 2A recording the highest bodyweights and testosterone concentrations (especially at 7 months of age) in agreement with studies in sheep by Orji (1976) and Osinowo and Abubakar (1988). Furthermore, Ration $\mathrm{C}$ also recorded some positive results compared to the other test ration (Ration $\mathrm{B}$ ) in that bucks fed on Ration 2C had heavier bodyweights and higher peak testosterone concentrations. From the economic and biological analyses reported herein, it can be recommended to smallholder goat farmers that test Ration C is a cheap, affordable and better crop-residue-based ration for optimal reproductive performance than test Ration B, and a good alternative to the expensive conventional concentrate Ration A.

\section{ACKNOWLEDGMENTS}

The authors gratefully acknowledge the support of the International Atomic Energy Agency (IAEA) Vienna, Austria in funding this project through provision of the hormonal assay kits and chemicals, and to the Director of the National Animal Production Research Institute, Ahmadu Bello University Shika-Zaria for permission to publish this work.

\section{REFERENCES}

Adu IF, Buvanendran V, Lakpini CAM. 1979. The reproductive performance of Red Sokoto goats in Nigeria. Journal of Agricultural Science (Cambridge) 93, 563-566.

Agarwal VK, Agarwal SP, Dixit NK. 1983. A twenty-four hour temporal variation in peripheral levels of testosterone and thyroid hormones in male buffaloes. Theriogenology 20, 37-45.

Alawa JP, Umunna NN. 1993. Alternative feed formulation in the developing countries: Prospects for utilisation of agro-industrial by-products. Journal of Animal Production Research 13, 63-98. 
Alderman G. 1985. Prediction of the energy value of compound feeds. In: Haresign W, Cole DJA (eds), Recent Advances in Animal Nutrition. Butterworths, London, UK.

Alhassan WS, Ehoche OW, Adu IF, Obilara TA, Kallah MS. 1984. Crop residue potential of agricultural development projects: Nutritive value and residue management. NAPRI Annual Report, pp. 35-45. National Animal Production Research Institute, Shika, Nigeria.

AOAC. 1980. Official Methods of Analysis, 13th edn. Association of Official Analytical Chemists, Washington DC, USA.

Dyrmundsson OR. 1973. Puberty and early reproductive performance in sheep. II. Ram lambs. Animal Breeding Abstracts 41, 419-424.

Ehoche OW, Buvanendran V. 1983. The yield and composition of milk and preweaning growth rate of Red Sokoto goats in Nigeria. World Review of Animal Production XIX, 19-24.

Fields MJ, Hentges RF, Kenneth W, Cornelisse KW. 1982. Aspects of the sexual development of Brahman versus Angus bulls in Florida. Theriogenology 18, 17-31.

Gefu JO, Adu IF. 1982. Observations on the herd size of sheep and goats in Kano State, Nigeria. World Review of Animal Production 18, 25-28.

Gerioff BJ. 1986. Effect of nutrition on reproduction in dairy cattle. In: Marrow DA (ed.), Current Therapy in Theriogenology, 2nd edn. WB Saunders, Philadelphia, USA.

Goering HK, Van Soest PJ. 1970. Forage fibre analysis (apparatus, reagents, procedures and some applications). Agricultural Handbook 379, ARS. USDA, Washington DC.

Ikhatua UI, Adu IF. 1984. A comparative evaluation of the utilisation of groundnut haulms and Digitaria hay by Red Sokoto goats. Journal of Animal Production Research 4, 145152.

INRA. 1988. Alimentation des bovins, ovins et caprins. Institut National de la Recherché Agronomique, Paris, France.

Karg H, Gimenez T, Hart LM, Hoffmann B, Schallenberger E, Schauns D. 1976. Testosterone, luteinising hormone and follicle stimulating hormone in peripheral plasma of bulls: levels from birth through puberty and short term variations. Zentralblatt Fur Veterinarmedizin 23, 793-803.

Lacroix A, Pelletier J. 1979. Short-term variations in plasma LH and testosterone in bull calves from birth to one year of age. Journal of Reproduction and Fertility 55, 81-85.

Lakpini CAM, Balogun BI, Alawa JP, Onifade OS, Otaru SM. 1997. Effects of graded levels sun-dried cassava peels in supplement diets fed to Red Sokoto goats in the first trimester of pregnancy. Animal Feed Science and Technology 67, 197-204.

Lunstra DD, Ford JJ, Echternkamp SE. 1978. Puberty in beef bulls: hormone concentrations, growth, testicular development, sperm production and sexual aggressiveness in bulls of different breeds. Journal of Animal Science 46, 1054-1062.

Mathewman RW. 1980. Small ruminant production in the humid tropical zone of Southern Nigeria. Tropical Animal Health and Production 12, 234-242.
McDonald P, Edwards RA, Greenhalgh JFD. 1988. Animal Nutrition, 4th edn. Longman Scientific and Technical, England, UK.

NRC. 1975. Nutrient Requirements of Domestic Animals, 5th edn. National Research Council, Washington DC.

Nuru S. 1985. Strategies for Improved Production of Fresh Foods in Nigeria. Nigerian Institute of Food Science and Technology, Federal Industrial Research Organisation (FIRO), Lagos, Nigeria.

Odell GD, Swedloff RS. 1974. The role of the gonad in sexual maturation. In: Grumbach MM, Grave GD, Mayer FE (eds), The Control of the Onset of Puberty. Wiley and Sons, New York.

Orji BI. 1976. Studies on the biology of reproduction of the Nigerian Dwarf sheep. PhD Thesis, The University of Ibadan, Nigeria.

Osinowo OA, Abubakar BY. 1988. Appropriate breeding strategies for small ruminant production in West and Central Africa. OAU/IBAR, Nairobi, Kenya.

Otchere EO, Ahmed HU, Adenowo IK, Kallah MS, Bawa EK, Olorunju SAS, Voh AA. 1987. Northern Nigeria: Sheep and goat production in the traditional Fulani agropastoral sector. World Animal Review 64, 50-54.

Oyedipe EO, Kumi-Diaka J, Osori DIK. 1981. Determination of the onset of puberty in Zebu bulls under tropical conditions of Northern Nigeria. Theriogenology 16, 419431.

Rekwot PI, Oyedipe EO, Akerejola OO, Kumi-Diaka J. 1987. The effect of protein intake on the onset of puberty in Bunaji and Friesian $\times$ Bunaji crossbred bulls in Nigeria. Theriogenology 28, 427-434.

Rekwot PI, Oyedipe EO, Dawuda PM, Sekoni VO. 1997. Age and hourly related changes of serum testosterone and spermiogram of pre-pubertal bulls fed two levels of nutrition. Veterinary Journal 153, 341-347.

Renaville R, Fabry J, Halleux V, Burny A. 1983. Testosterone plasma profiles as a function of age in young bulls from the bovine double-muscled Belgian White Blue breed. Theriogenology 19, 159-167.

Sanwal PC, Sundby A, Edquist LE. 1974. Diurnal variations of $\mathrm{LH}, \mathrm{FSH}$, prolactin and testosterone in peripheral plasma of pre-pubertal bulls. Journal of Reproduction and Fertility 54, 145-148.

SAS. 1987. Statistical Analysis System. SAS Institute, Cary, North Carolina.

Setchell BP, Waites GMH, Lindner HR. 1965. Effect of undernutrition on testicular body flow and metabolism and the output of testosterone in the ram. Journal of Reproduction and Fertility 9, 149-157.

Silva AT, Orskov ER. 1988. The effect of five different supplements on the degradation of straw in sheep given untreated barley straw. Animal Feed Science and Technology 19, 289-298.

Swan H, Lamming GE. 1967. Studies on the nutrition of ruminants. II. The effect of crude fibre in maize-based rations on the carcass composition of Friesian steers. Animal Production 9, 203-208. 